\title{
BRANDING JURNAL KEWIRAUSAHAAN DAN BISNIS
}

\section{Susantiningrum, Bara Yudhistira, Dimar Hantari}

\author{
Pusat Pengembangan Kewirausahaan LPPM Universitas Sebelas Maret, Jl. Ir. Sutami No.36A, \\ Kentingan, Jebres, Surakarta, Indonesia, 57126 \\ Email: susantiningrum@staff.uns.ac.id
}

\begin{abstract}
ABSTRAK
Jurnal Kewirausahaan dan Bisnis (JKB) Pusat Pengembangan Kewirausahaan (PPKwu) telah memiliki ISSN cetak dan ISSN elektronik. Kegiatan ini bertujuan untuk meningkatkan kualitas dan kapasitas manajemen dan pengelolaan PPKwu khususnya dalam mengelola Jurnal Kewirausahaan dan Bisnis menuju jurnal bereputasi yaitu dengan dengan memperbaiki konten dan tampilan jurnal. Kegiatan dilakukan dengan menerapkan metode campuran antara kuantitatif dan kualitatif, serta dengan menerapkan analisis komparatif untuk membandingkan kondisi JKB sebelum dan sesudah kegiatan dilaksanakan. Dengan dilaksanakan kegiatan ini diharapkan JKB dapat menjadi jurnal yang bereputasi dan memiliki kualifikasi yang cukup untuk mendaftar akreditasi jurnal nasional. Kegiatan yang telah dilakukan antara lain: workshop perbaikan logo dan header jurnal, workshop perbaikan content, indeksasi DOAJ, perbaikan DOI, workshop perbaikan cover jurnal cetak dan pembautan brosur.
\end{abstract}

Kata kunci: akreditasi, institusi, jurnal, kewirausahaan

\begin{abstract}
Jurnal Kewirausahaan dan Bisnis (JKB), Entrepreneurship Development Center (PPKwu) has printed ISSN and electronic ISSN. This activity aims to improve the quality and capacity of management PPKwu, especially in managing journal towards reputable journals, such as by improving the content and appearance of the journal. The activity is carried out by applying a mixture of quantitative and qualitative methods, and by applying a comparative analysis to compare the conditions of JKB before and after the activities are carried out. By carrying out this activity it is hoped JKB can become a reputable journal and have sufficient qualifications to register for national journal accreditation. Activities that have been carried out include: a workshop to improve journal logos and headers, a workshop to improve content, DOAJ indexation, DOI repairs, workshops to improve print journal covers and brochure development.
\end{abstract}

Key words: accreditation, entrepreneurship, institution, journal 


\section{PENDAHULUAN}

Kewirausahaan merupakan salah satu program unggulan di Universitas Sebelas Maret (UNS). Hal tersebut diimplementasikan dalam salah satu budaya kerja UNS yaitu Entrepreneurship. Dalam rangka mendukung program-program unggulan UNS khsususnya dalam bidang kewirausahaan, Pusat pengembangan kewirausahaan (PPKwu) Lembaga Penelitian dan Pengabdian kepada Masyarakat (LPPM) Universitas Sebelas Maret (UNS) memiliki Visi menjadi pusat riset dan layanan yang profesional, unggul dan terdepan di bidang kewirausahaan dan pengembangan bisnis bagi warga kampus dan masyarakat. Adapun misinya yaitu: 1) mewujudkan institusi PPKwu yang handal dan terpercaya; 2) membudayakan mengimplementasikan nilai-nilai kewirausahaan dalam kehidupan warga kampus dan masyarakat; 3) menumbuhkan wirausaha-wirausaha baru dari kalangan terdidik; 4) mewujudkan pelaku bisnis mikro, kecil, menengah, dan koperasi yang profesional, mandiri dan inovatif yang berwawasan iptek; 5) mewujudkan pusat kepakaran dalam bidang kewirausahaan dan pengembangan bisnis.

Telah banyak hasil-hasil penelitian dan pengabdian di bidang kewirausahaan yang dilakukan oleh PPKwu dalam rangka menjadi pusat mandiri professional yang bergerak di bidang kewirausahaan. Bentuk profesionalitas yang telah dilakukan adalah menerbitkan Jurnal Ilmiah di bidang kewirausahaan yang diberi nama "Jurnal Kewirausahaan dan Bisnis". Media publikasi praktisi ataupun akademisi yang mempublikasikan hasil penelitian salah satunya adalah jurnal ilmiah (Meitriana dan Zukhri, 2017). Jurnal ilmiah memiliki substansi yang lebih berkualitas (Almah, 2015).

Kegiatan ini bertujuan untuk meningkatkan kualitas dan kapasitas manajemen dan pengelolaan PPKwu khususnya dalam mengelola Jurnal Kewirausahaan dan Bisnis menuju jurnal bereputasi.

\section{METODE}

Kegiatan Pengembangan Jurnal Kewirausahaan dan Bisnis Menuju Jurnal Bereputasi ini dilakukan pada bulan Maret-Oktober 2019 dan bertempat di Gedung LPPM UNS Lantai II, Jl. Ir. Sutami No.36A Kentingan Surakarta 57126.

Metode kegiatan yang digunakan adalah metode campuran, dimana kombinasi antara metode kuantitatif dan kualitatif yang dapat memberikan pemahaman lebih baik tentang permasalahan penelitian. Studi kombinatif memanfaatkan kekuatan relatif dari data kuantitatif sekaligus data kualitatif. (Mertler, 2011). Adapun tahapan kegiatan antara lain:

1) Workshop perbaikan logo Jurnal Kewirausahaan dan Bisnis

2) Workshop perbaikan tampilan website Jurnal Kewirausahaan dan Bisnis

3) Workshop penyusunan program peningkatan Jurnal Kewirausahan 
dan Bisnis dalam rangka Jurnal Kewirausahaan dan Bisnis. pengajuan akreditasi nasional Untuk menarik perhatian calon

4) Menerbitkan mempublikasikan Kewirausahaan dan Bisnis ke seluruh Indonesia.

\section{HASIL DAN PEMBAHASAN}

Penilaian akreditasi oleh DIKTI termasuk didalamnya adalah tampilan jurnal yang menarik (Direktorat Jenderal Penguatan Riset dan Pengembangan, 2018).

1. Workshop Perbaikan Logo dan Header Website Jurnal

Salah satu upaya meningkatkan branding index PPKwu adalah melalui penulis, tampilan website juga harus dibuat semenarik mungkin. Tampilan yang menarik juga meningkatkan kepercayaan calon penulis untuk submit di Jurnal Kewirausahaan dan Bisnis. Untuk itu perlu dilakukan perbaikan logo, header dan cover jurnal cetak. Workshop perbaikan logo jurnal dilaksanakan pada 14 Juni 2019 di Ruang Sidang 1 LPPM UNS. Perbaikan ini dihadiri oleh narasumber yang ahli dibidang desain. Dalam workshop ini dihasilkan output berupa logo baru Jurnal Kewirausahaan dan Bisnis.

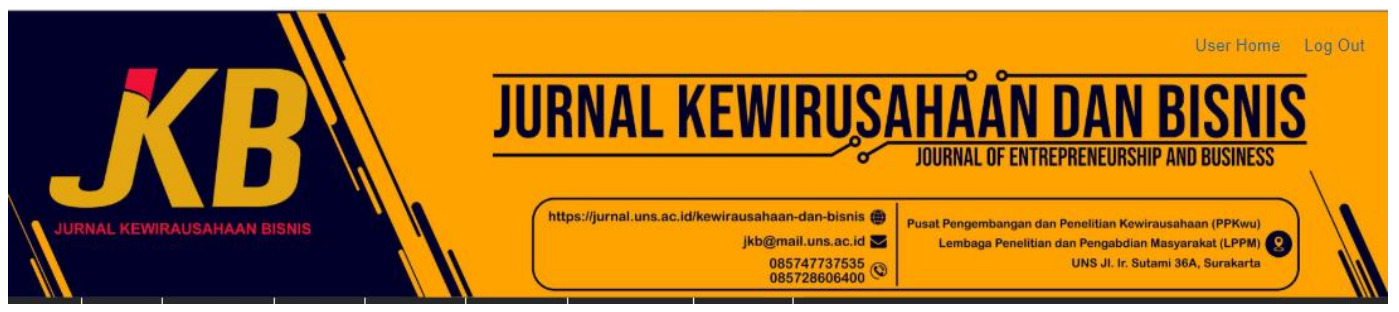

Gambar 1. Logo dan Header Jurnal

2. Workshop Perbaikan Content

Workshop perbaikan content dilakukan pada tanggal 21 Juni 2019 di Ruang Sidang 1 Lantai 1 LPPM UNS. Kegiatan yang dilakukan antara lain:

a. Menambah content:
1) Deskripsi Jurnal
2) Fokus dan Ruang Lingkup
3) Proses Review
4) Biaya Penulis

5) Plagiat

6) Pengiriman Daring

b. Memperbaiki content:

1) Frekuensi Publikasi

2) Kebijakan Akses Terbuka

3) Pemberitahuan Hak Cipta

4) Pernyataan Privasi

c. Serta mengubah Bahasa dari Indonesia ke Bahasa Inggris. 


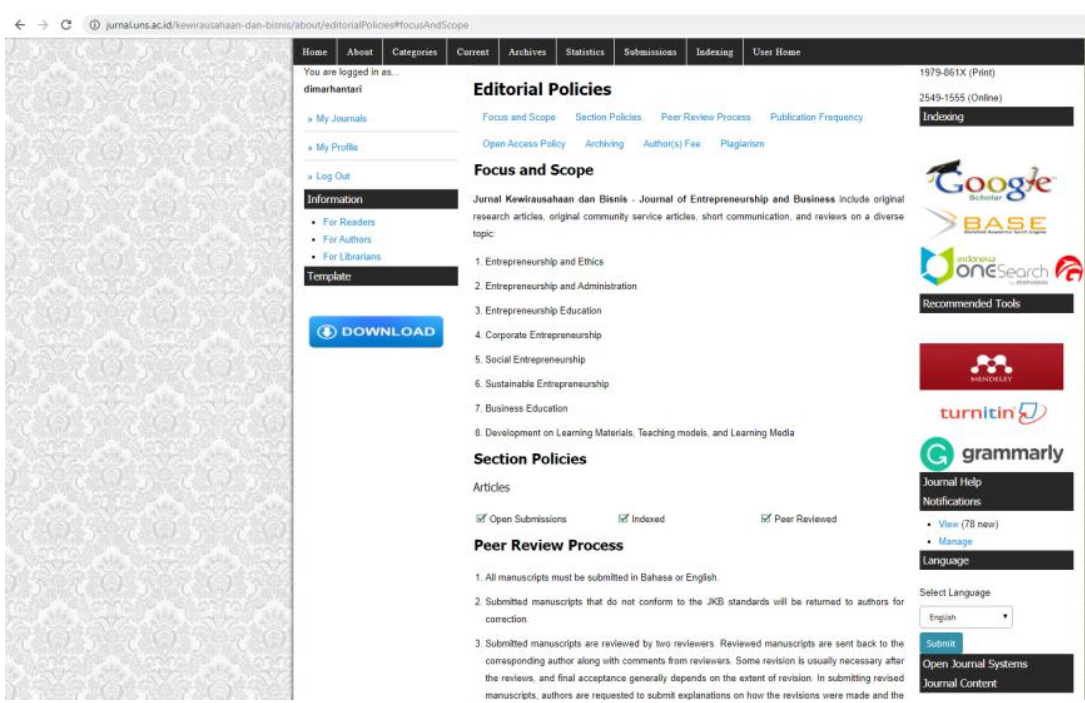

Gambar 2. Content yang telah diperbaiki

3. Indeksasi DOAJ

Pendaftaran jurnal pada lembaga indeks bereputasi adalah indeksasi (Widodo et al., 2017). Manfaat jurnal terindeks yaitu memungkinkan tingkat akses metadata jurnal yang semakin tinggi (Junadi, 2018).

Indeksasi DOAJ dilakukan pada tanggal 01 Juli 2019. Terdapat 58 pertanyaan yang harus diisi untuk indeksasi DOAJ. Beberapa bagian dalam formulir pengisian pengajuan indeksasi antara lain:
a. Informasi Jurnal Dasar
b. Kualitas dan Transparansi Proses Editorial
c. Seberapa Terbuka Jurnal
d. Lisensi Konten
e. Hak Cipta dan Izin
f. Kualifikasi untuk DOAJ Seal
g. Nama Kontak

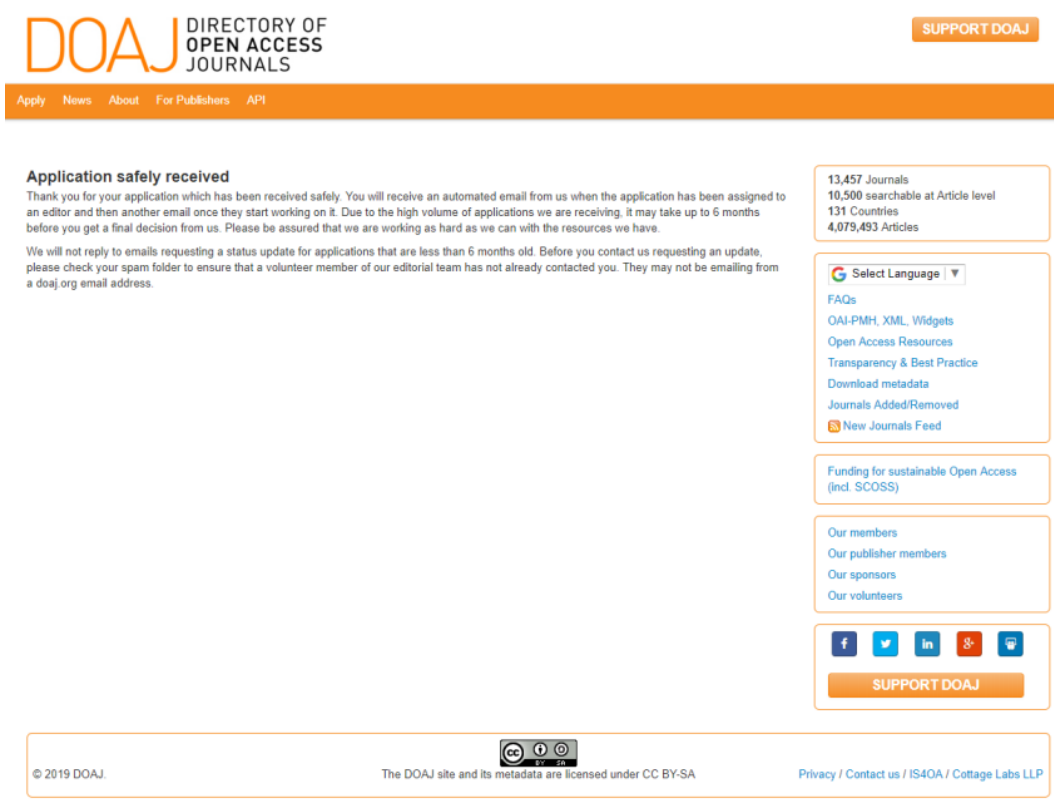

Gambar 3. Pendaftaran DOAJ 
4. Workshop Perbaikan Cover Jurnal Cetak

Jurnal Kewirausahaan dan

Bisnis telah mengeluarkan jurnal versi cetak sejak tahun 2007. Sejak tahun 2017 tersebut, belum pernah ada perbaikan ataupun perubahan cover jurnal tersebut. Workshop perbaikan jurnal cetak di lakukan pada tanggal 08 Agustus 2019 di Ruang Sidang 1 LPPM UNS. Hasil dari perbaikan cover jurnal dapat dilihat pada gamba dibawah.

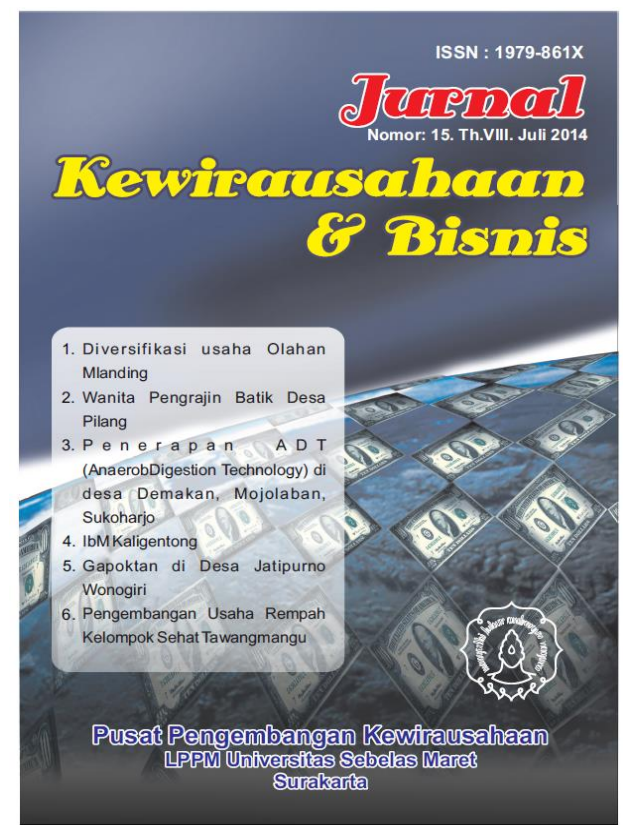

(a)

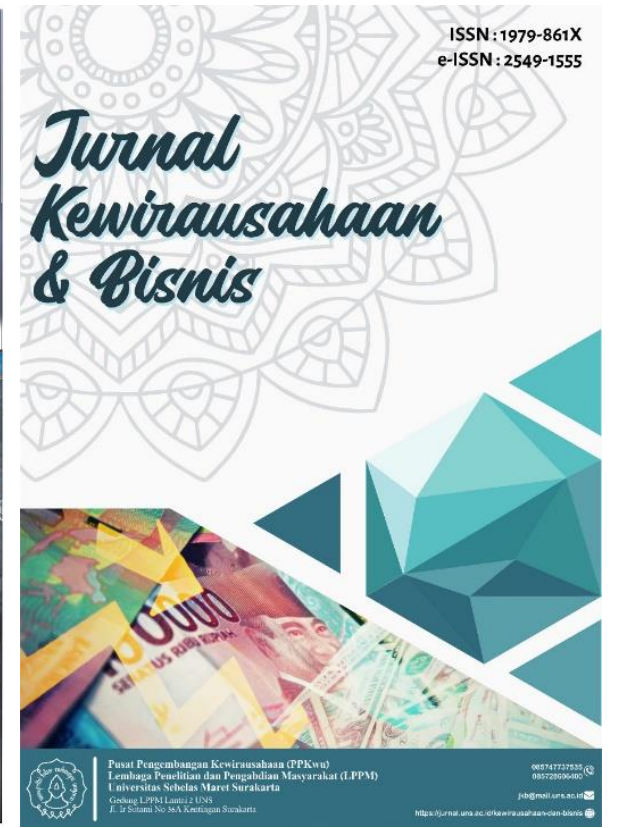

(b)

Gambar 4. Cover Jurnal Cetak (a) Sebelum dan (b) Setelah diperbaiki

Hal-hal yang diperbaiki dalam cover jurnal tersebut antara lain:

a. Desain dan warna cover

b. Penambahan logo, nama dan alamat lembaga penerbit

c. Penambahan nomor telepon, email dan website Co-Editor dan Assistant Editor.
5. Pembuatan Brosur Jurnal

Brosur jurnal dibuat dengan maksud untuk menyebarluaskan informasi mengenai Jurnal Kewirausahaan dan Bisnis di kalangan dosen dan peneliti baik UNS maupun luar UNS agar mereka dapat submit di Jurnal Kewirausahaan dan Bisnis. 


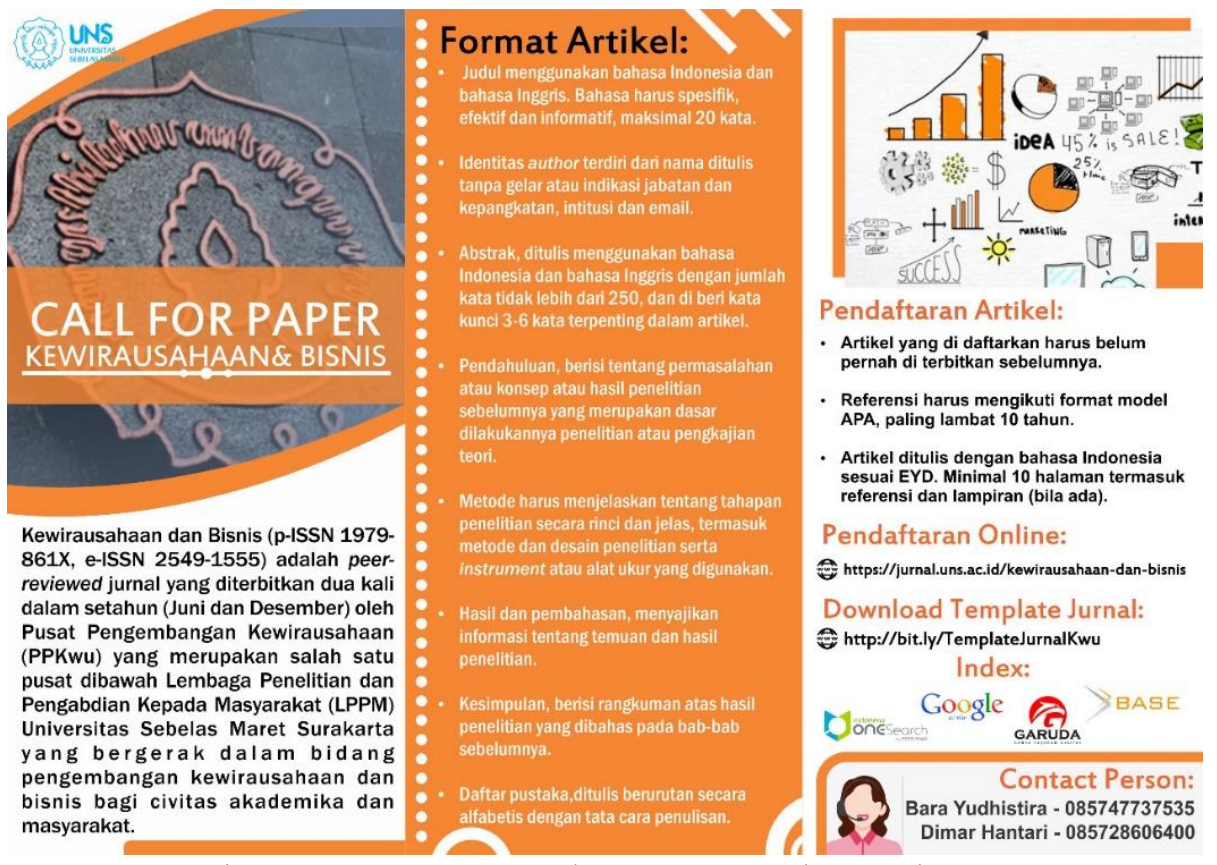

Gambar 5. Brosur Jurnal Kewirausahaan dan Bisnis

\section{Penyusunan Draft SK Ketua} LPPM

Upaya untuk meningkatkan kepercayaan dan loyalitas reviewer serta editorial board maka diperlukan legalitas. Legalitas tersebut berupa Surat Keputusan yang di keluarkan oleh Ketua LPPM UNS. Penyusunan draft ini, didahului dengan proses surat menyurat kepada reviewer dan editor untuk mendapatkan surat pernyataan kesediaan menjadi reviewer dan editor.

\section{KESIMPULAN}

Berdasarkan hasil kegiatan, dapat disimpulkan bahwa seluruh kegiatan telah berjalan. Kegiatan yang telah dijalankan antara lain: koordinasi kegiata, submit ke lembaga indeks nasional, Workshop simulasi penilaian jurnal menuju akreditasi nasional, dan Workshop Program Percepatan Akreditasi
Nasional JKB, Workshop Pembuatan Template Jurnal, Pelatihan OJS, dan Publikasi Junal.

\section{DAFTAR PUSTAKA}

Almah, H. 2015. Eksistensi Jurnal Ilmiah di Universitas Islam Negeri Alauddin Makassar (Perannya dalam Mendukung Universitas Islam Negeri Alauddin Makasar menuju World-Class University). Jurnal Ilmu Perpustakaan, Informasi, dan Kearsipan Khizanah Al-Hikmah. Vol. 3 (2): 172-184.

Direktorat Jenderal Penguatan Riset dan Pengembangan. 2018. Pedoman Akreditasi Jurnal Ilmiah. Kementerian Riset, Teknologi, dan Pendidikan Tinggi. Jakarta.

Junadi, S. 2018. Pengelolaan Jurnal Elektronik Bidang Perpustakaan Menuju Jurnal 
Terakreditasi. PUSTABIBLIA:

Journal of Library and Information Science, 2 (1): 119136.

Meitriana, M. A., \& Zukhri, A. 2017. Revitalisasi Jurnal Ilmiah "Ekuitas" Berbasis Open Journal System. Proceeding Conference. Universitas Pendidikan Ganesha, Singaraja, Bali.

Widodo et al. 2017. Panduan Indeksasi, Manajemen Referensi, dan Akreditasi Jurnal. Yogyakarta: Gadjah Mada University Press. 